\title{
IDENTIFIKASI FENOMENA HUJAN ES BERBASIS ANALISIS FAKTOR CUACA MENGGUNAKAN CITRA SATELIT HIMAWARI-8 DAN DATA UPPER AIR SOUNDING (STUDI KASUS : KEJADIAN HUJAN ES TANGGAL 20 MARET 2018 DI DEPOK)
}

\author{
FAJAR SIDIQ ARIWIBOWO *, ANANG AHMAD KHAIRIN NUR, INDRA \\ Prodi Meteorologi, \\ Sekolah Tinggi Meteorologi Klimatologi dan Geofisika Jl.Perhubungan 1 no 5, Pondok Betung \\ Kec Pondok Aren Tangerang Selatan \\ * email : rahmatthekickers@gmail.com
}

\begin{abstract}
Abstrak. Pada tanggal 20 Maret 2018 telah terjadi fenomena langka berupa hujan es disertai petir dan angin kencang di beberapa wilayah kota Depok. Berkaitan dengan hal itu dilakukan penelitian berdasarkan analisis data citra satelit Himawari-8 kanal IR menggunakan software SATAID dapat diketahui bahwa suhu puncak awan mengalami penurunan yang signifikan mencapai $-73,2{ }^{\circ} \mathrm{C}$ dan diperoleh nilai indeks CAPE (Convective Available Potential Energy) sebesar $1093 \mathrm{~J} / \mathrm{kg}$ yang mendeskripsikan kondisi stabilitas atmosfer. Berdasarkan anomali SST menunjukan perairan di lautJawa dan Samudera Hindia menghangat berkisar antara $1,0-1,5{ }^{\circ} \mathrm{C}$ sehingga mendukung pembentukan awan konvektif. Peta streamline menunjukan adanya belok anangin sehingga menimbulkan penumpukan massa udara dan pembentukan awan konvektif diatas sebagian besar wilayah pulau Jawa. Hasil penelitian dan analisis sounding dengan menggunakan software RAOB diperoleh lapisan freezing level pada ketinggian $4950 \mathrm{~m}$ dan temperature surface di kota depok berkisar $24,0-25,0^{\circ} \mathrm{C}$ sehingga memungkinkan jatuhnya endapan dalam bentuk kristal es.
\end{abstract}

Kata kunci :Hujan Es, SATAID, RAOB

Abstract.On March 20, 2017 there has been a rare phenomenon in the form of hail accompanied by lightning and strong winds in some areas of the city of Depok. In that regard do research based on analysis of satellite imagery data Himawari- 8 channel IR using SATAID software can be seen that the temperature of the cloud tops had a significant reduction reached $-73.2^{\circ} \mathrm{C}$ and obtained an index value of CAPE (Convective Available Potential Energy) of $1093 \mathrm{~J} / \mathrm{kg}$ describing atmospheric stability conditions. Based on SST anomalies show in the Java Sea and the waters of the Indian Ocean warmed up ranged from 1.0 to $1.5^{\circ} \mathrm{C}$ thus favoring the formation of convective clouds. Map streamlined curves showed the presence of wind, causing a buildup of air masses and the formation of convective clouds over large parts of the island of Java. The result of the research and analysis sounded by using RAOB software obtained freezing level at 4950 $\mathrm{m}$ height and surface temperature in depok city according to $24.0-25,0^{\circ} \mathrm{C}$ so as to enable the fall of sediment in the form of ice crystals.

Keywords :Hail, SATAID, RAOB

\section{Pendahuluan}

Fenomena hujan es biasanya terjadi pada wilayah ekstra-tropis karena memiliki lapisan beku (freezing level) yang relative lebih rendah (Fadholi, 2012). Freezing level ini adalah ketinggian dimana lapisan atmosfer memiliki suhu $0^{\circ} \mathrm{C}$ sehingga 
tetes air membeku. Freezing level pada wilayah tropis lebih tinggi di banding dengan wilayah ekstra-tropis karena suhu permukaan wilayah tropis lebih tinggi daripada wilayah ektra-tropis yang suhunya lebih rendah. Hujan es juga dapat terjadi di wilayah tropis seperti Indonesia yang memiliki suhu udara permukaan yang hangat dan kelembaban udara yang cukup tinggi meskipun pada musim kemarau (Karmini, 2000).

Pada tanggal 20 Maret 2018 telah terjadi kejadian cuaca ekstrim di wilayah Kabupaten Depok dengan di tandai hujan dengan intensitas lebat disertai petir dan es. Sebagaimana telah diketahui, fenomena hujan disertai es merupakan fenomena ekstrim yang jarang dan tidak lazim terjadi. Peluang terjadinya pertumbuhan awan konvektif yang menjadi salah satu penyebab cuaca ekstrim sangat besar berdasarkan faktor regional dan local seperti efek siklon tropis, eddy, dan daerah shearline (daerah belokan angin). Berdasarkan beberapa kajian baik menggunakan radar cuaca maupun satelit cuaca GOES dan MSG menyebutkan bahwa fenomena hail bias terjadi pada kondisi awan konvektif tebal yang memiliki updraft kuat (Rosenfeld dkk., 2008), (Merino dkk., 2014), (Liu dkk., 2015).

Penelitian ini dilakukan untuk membahas lebih lanjut penyebab terjadinya hujan es berdasarkan analisa faktor cuaca skala global, meridional dan lokal menggunakan citra satelit Himawari-8 dan Data Upper Air Sounding. Hasil dari penelitian dapat digunakan untuk memahami fenomena hujan es yang tidak lazim terjadi di daerah tropis dengan kondisi cuaca relatif lembab dan penerimaan radiasi jauh lebih besar daripada daerah sub tropis dan kutub. Selain itu pemahaman tentang penyebab terjadinya hujan es dapat digunakan sebagai acuan dalam mengantisipasi dampak yang ditimbulkan oleh hujan es

\section{Metode Penelitian}

Data yang digunakan dalam penelitian ini adalah data faktor cuaca skala global, regional, dan lokal. Faktor cuaca skala global yang akan dianalisis terdiri dari data suhu permukaan laut/sea surface temperature (SST), data ENSO berupa grafik indeks Nino 3.4 serta data SOI diakses melalui http://www.bom.gov.au. Analisis pengaruh cuaca regional menggunakan data Madden Julian Oscillation (MJO) diperoleh dari http://www.bom.gov.au/climate/mjo/ dan peta streamline yang diperoleh dari http://www.bom.gov.au/australia/charts/archive/. Analisis pengaruh cuaca skala lokal menggunakan data pengamatan sinoptik Stasiun Klimatologi Bogor $\left(6,93^{\circ} \mathrm{LS} 107,58^{\circ} \mathrm{BT}\right)$ dan Stasiun Meteorologi Citeko (xxx), yaitu meliputi tekanan, suhu, kelembapan, arah dan kecepatan angin. Selain itu, analisis kondisi atmosfer dilaksanakan dengan menggunakan data citra satelit Himawari-8 kanal IR dengan ekstensi .z yang kemudian diolah menggunakan aplikasi SATAID. Penggunaan teknik Red Green Blue (RGB) digunakan dalam penelitian ini untuk analisis pola spasial awan dengan intepretasi warna. Terakhir, dalam penelitian ini dipergunakan software Raob 5.7R untuk menganalisis data Upper Air Sounding.

Stasiun Meteorologi Cengkareng. Sehingga diperoleh profil atmosfer secara vertikal dan ketinggian lapisan freezing level dimana data tersebut diperoleh dari http://www.weather.uwyo.edu/upperair/sounding.html. 


\section{Hasil dan Pembahasan}

\section{Analisa Pengaruh Cuaca Skala Global Southern Oscillation Index}

Grafik ENSO memiliki kecenderungan untuk tetap netral. Ketika ENSO netral, pola cuaca diatas wilayah Pasifik akan mendekati normal, sehingga kondisi iklim di wilayah Benua Australia tidak terlalu kering atau terlalu basah dibanding normal. Sementara itu, nilai Southern Oscillation Index (SOI) pada Bulan Maret 2018 yang ditunjukkan pada grafik berkisar antara -5 hingga -10 yang termasuk kategori La Nina kuat, fenomena ini disebabkan oleh kuatnya angin pasat di samudera pasifik dan meningkatnya suhu permukaan laut di utara Australia dan Indonesia bagian timur. Air laut dibagian tengah dan timur pasifik mengalami penurunan suhu selama periode ini. Membuat meningkatnya kemungkinan kenaikan kelembapan didaerah bagian barat pasifik ( Indonesia dan Australia).

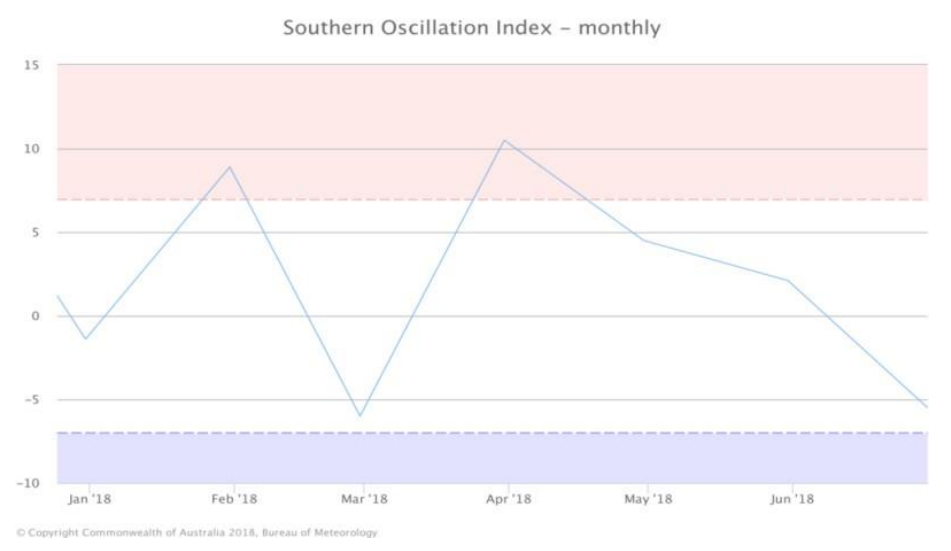

Gambar 1. Grafik Variabilitas Indeks SOI bulan Januari - Juni 2018 (Sumber : http://www.bom.gov.au/climate/current/soi2.shtml)

\section{Analisis Sea Surface Temperature (SST)}

Peta Sea Surface Temperature pada gambar 2 digunakan untuk menganalisis suhu permukaan laut pada perairan Indonesia, tepatnya di kawasan Laut Jawa di dekat Samudra Hindia, digunakan model pola gradiasi pewarnaan suhu permukaan laut dalam skala nilai. Dalam hal ini, ditemukan adanya indikasi peningkatan Sea Surface Temperature di perairan Laut Jawa dengan nilai antara $29-29.4{ }^{\circ} \mathrm{C}$ sehingga terdapat anomali sebesar $1,0-1,5{ }^{\circ} \mathrm{C}$. Rentang nilai anomali tersebut menunjukkan jika faktor SST mendukung laju penguapan yang memicu terbentuknya awan-awan konvektif berupa cumulonimbus matang yang mengandung partikel es tersebar di sebagian besar wilayah kota Depok. 


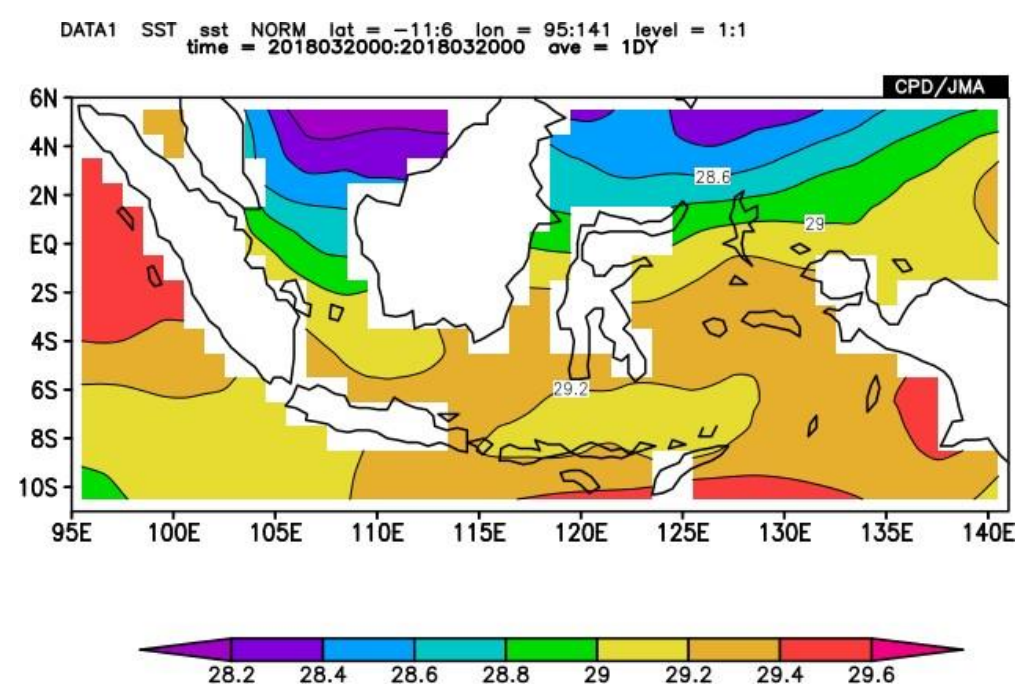

Gambar 2. Sea Surface Temperature (SST) Bulan 20 Maret 2018 (Sumberhttp://extreme.kishou.go.jp/itacs5/)

\section{Analisis Pengaruh Cuaca Skala Regional}

\section{Analisis Outgoing Longwave Radiaton (OLR)}

Selain menggunakan model pola gradiasi pewarnaan suhu permukaan laut, pengamatan Outgoing Longwave Radiation atau yang lebih familiar disebut radiasi gelombang panjang juga dilakukan guna mengetahui radiasi matahari yang dipantulkan oleh bumi ke luar angkasa. Pada gambar menunjukkan kawasan sebagian besar pulau Jawa, Sumatera Selatan, dan Kalimantan memantulkan sedikit radiasi gelombang panjang. Hal ini membuktikan, bahwa permukaan bumi menyerap lebih banyak radiasi matahari yang diterimanya daripada yang dipantulkan. Dengan tingginya kemampuan permukaan bumi dalam menyerap radiasi matahari, permukaan bumi akan menjadi semakin panas. Akibatnya, aktivitas pertumbuhan awan-awan konvektif semakin meningkat hingga membentuk awan Cumulonimbus dengan konsentrasi es yang padat pada bagian puncaknya. Adanya awan-awan konvektif ini menyebabkanterhalangnya laju keluarnya gelombang radiasi matahari yang dipantulkan bumi, sehingga semakin sedikit radiasi gelombang inframerah yang tertangkap sensor satelit.

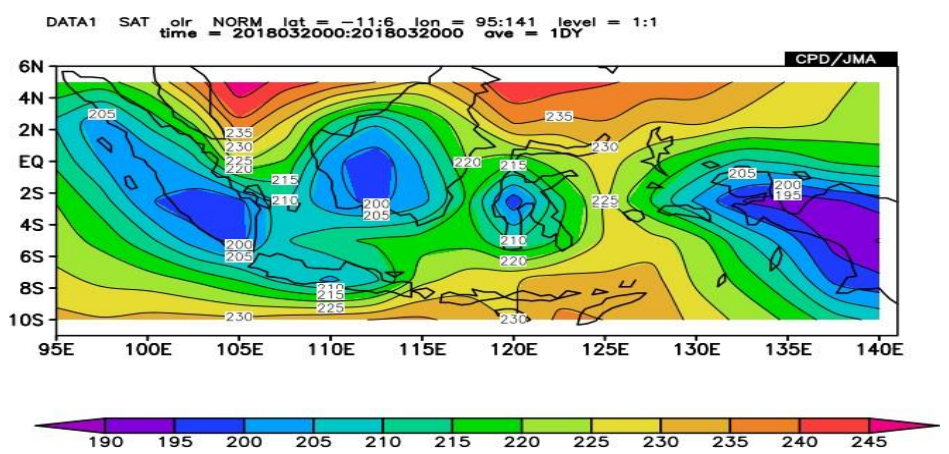

Gambar 3. Peta Outgoing Long Wave Radiation tanggal 20 Maret 2018 


\section{Analisis Peta Streamline}

Peta streamline pada gambar 4 menunjukkan adanya shearline di sekitar wilayah pulau jawa dan kota Depok. Shearline merupakan daerah dimana terjadi perubahan arah dan kecepatan angin secara tiba-tiba dimana kecepatan angin cenderung menurun sehingga menyebabkan penumpukan massa udara penyebab cuaca ekstrim. Streamline tanggal 20 Maret 2018 pukul $00.00 \mathrm{Z}$ menunjukkan adanya fenomena siklon tropis di perairan samudera hindia. Selain itu teramati siklus Eddy di perairan Selat Makassar hal tersebut semakin menguatkan potensi terjadinya cuaca ekstrim berupa hujan es di beberapa lokasi di Depok dengan keberadaan gugusan awan cumuluniform.

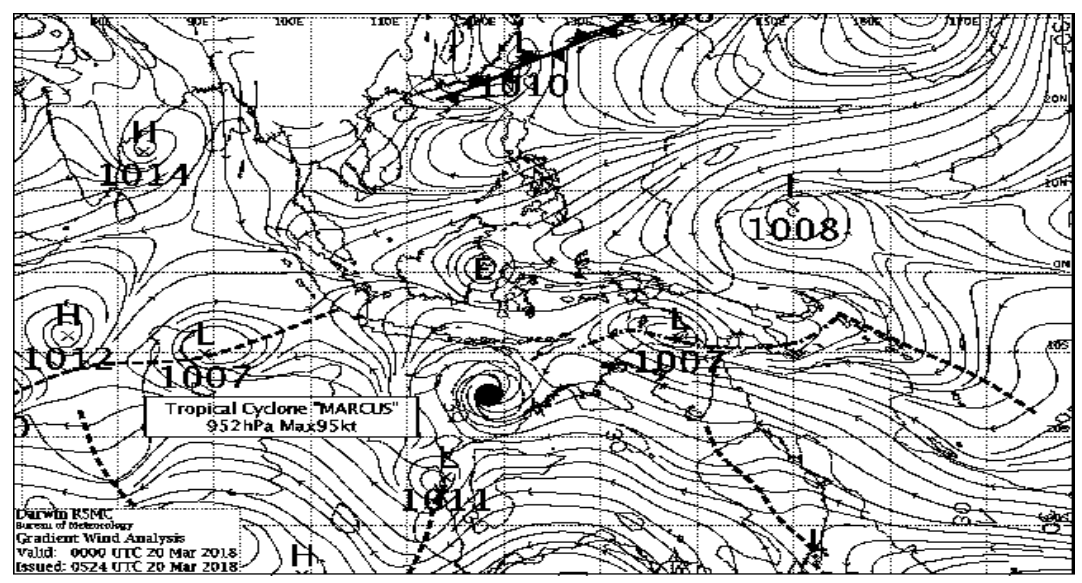

Gambar 4. Peta Streamline tanggal 20 Maret 2018 (Sumber: http://www.bom.gov.au/australia/charts/index.shtml)

\section{Analisis Faktor Cuaca Skala Lokal}

\section{Analisis Data Pengamatan Sinoptik}

Data unsur-unsur cuaca permukaan diperoleh dari Stasiun Klimatologi Bogor yang memiliki koordinat $6^{\circ} 33^{\prime} 12.39^{\prime \prime} \mathrm{S}-106^{\circ} 44^{\prime} 37.11^{\prime \prime T}$ dan StasiunMeteorologi Kemayoran yang meiliki koordinat sedangkan hujan es terjadi pada koordinat $6^{\circ}$ 9'20.12"S - 106 50 '29.87"T. Meskipun hujan es tidak terjadi pada koordinat ini, namun kedekatan jarak antara lokasi kejadian dengan Stasiun Geofisika Bandung sebagai kepanjangan tangan BMKG wilayah Bandung, maka juga dilakukan pendekatan melalui hasil pengamatan sinoptik jam 00.00Z hingga $07.00 \mathrm{Z}$ (waktu kejadian) sebagai bahan analisis dan ditampilkan oleh Grafik 1 dan Grafik 2 berikut: 


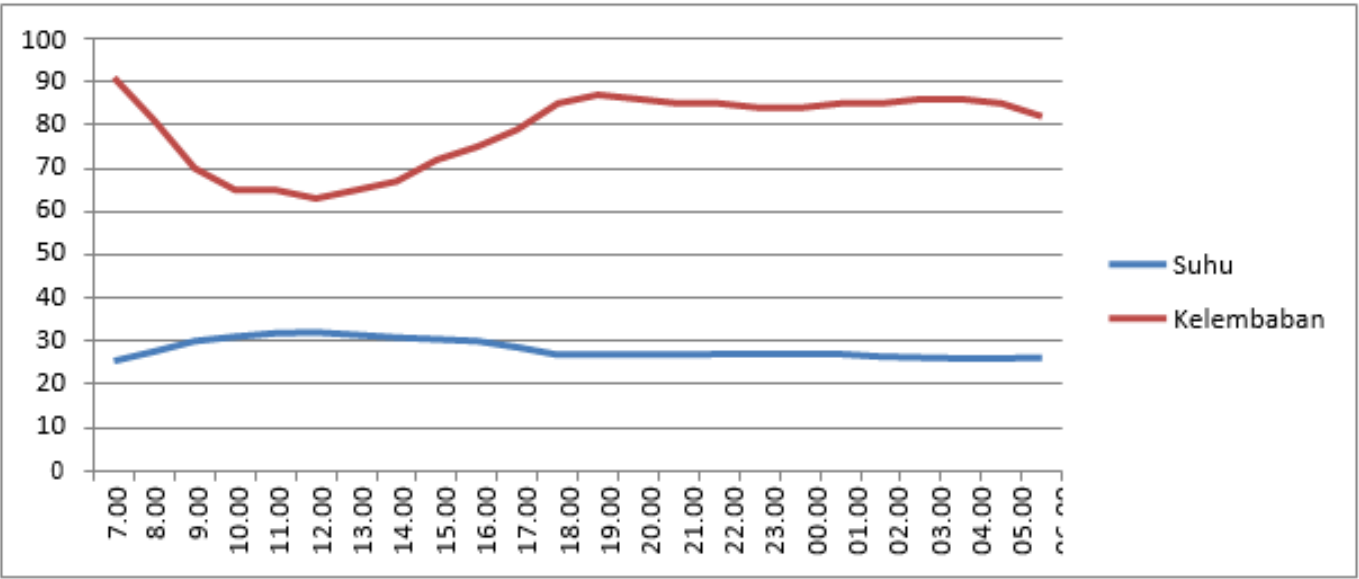

Grafik 1. Suhu dan Kelembaban Stasiun Meteorologi Kemayoran Tanggal 20 Maret 2018

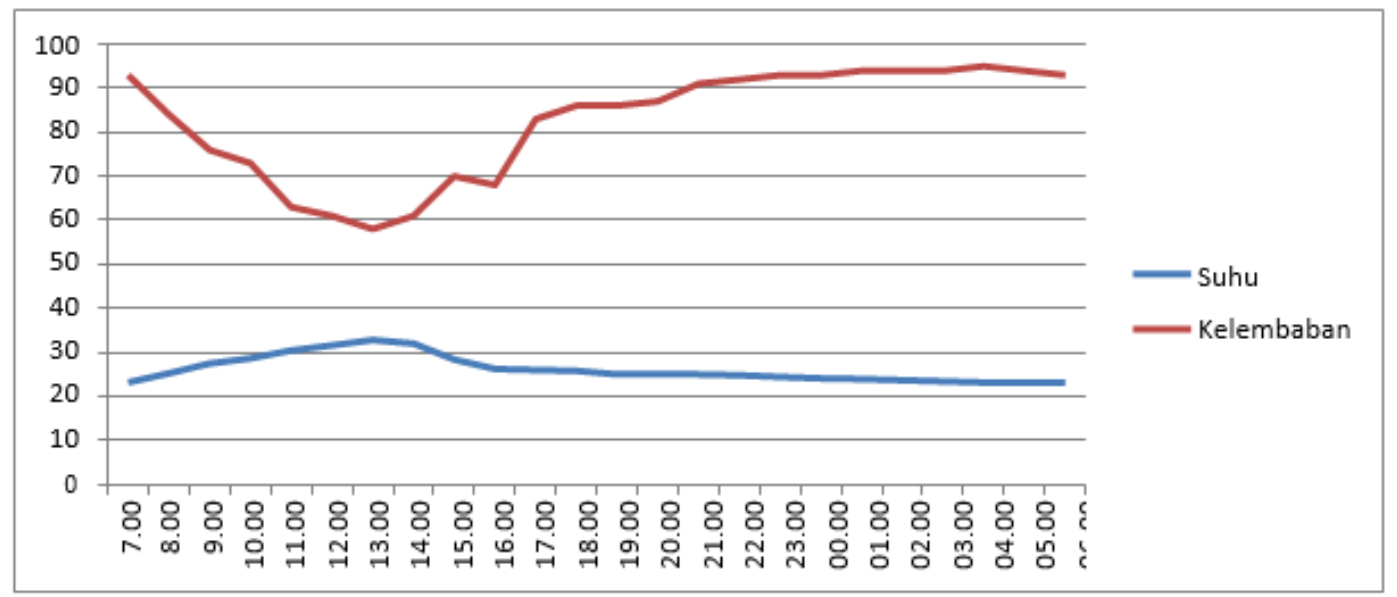

Grafik 2. Suhu dan Kelembaban Stasiun Klimatologi Bogor Tanggal 20 Maret 2018

\section{Analisis Data Upper Air Sounding}

Berdasarkan analisis menggunakan data upper air sounding menggunakan software Raob 5.7R di Stasiun Meteorologi Cengkareng pada tanggal 20 Maret 2018 jam 00 UTC diperoleh informasi ketinggian lapisan freezing level dengan suhu udara sebesar $0{ }^{\circ} \mathrm{C}$ berada pada ketinggian 4701 meter di atas permukaan laut. Hal ini menunjukan bahwa pada saat terjadi hujan es terdapat anomaliketinggian lapisan freezing level yang lebih rendah dibandingkan normalnya. Anomali tersebut memungkinkan partikel padat berupa butiran / kristal es pada puncak awan Cumulonimbus jatuh ke permukaan bumi sebagai hujan es tanpa mengalami proses melting terlebih dahulu. Hujan es terjadi di beberapa tempat di Depok dengan ketinggian permukaan tanah berkisar \pm 200 - 300 meter dari permukaan laut antara lain : Perkapuran, Beji, Juanda, Sukmajaya dan Kelapa Dua. Analisa kondisi atmosfer pada ketinggian 200 - 300 meter dari permukaan laut menunjukan suhu relatif lebih dingin dengan kelembapan yang cukup tinggi. Hal ini membuktikan bahwa kondisi lingkungan pada saat kejadian hujan es sangat mendukung. 


\begin{tabular}{|c|c|c|c|c|c|c|c|}
\hline Level & $\begin{array}{c}\text { Height } \\
\text { [m-MSL] }\end{array}$ & $\begin{array}{l}\text { Pres } \\
\text { (mb) }\end{array}$ & $\begin{array}{c}T \\
\text { (C) }\end{array}$ & $\begin{array}{l}\text { Td } \\
\text { (C) }\end{array}$ & $\begin{array}{l}\mathrm{RH} \\
{[\%]}\end{array}$ & $\begin{array}{c}\mathrm{DD} / \mathrm{FF} \\
\text { [deg/kts] }\end{array}$ & $\begin{array}{l}\text { CAT } \\
\text { (FAA) }\end{array}$ \\
\hline 1 & 8 & 1010 & 23,8 & 23,0 & 95 & $0 / 0$ & \\
\hline 2 & 52 & 1005 & 24,6 & 21.7 & 84 & & LGT \\
\hline 3 & 95 & 1000 & 25,2 & 21,2 & 79 & $190 / 4$ & \\
\hline 4 & 301 & 977 & 25,2 & 19,2 & 69 & & MDT \\
\hline 5 & 313 & 976 & & & & $340 / 3$ & \\
\hline 6 & 618 & 942 & & & & $345 / 4$ & LGT \\
\hline 7 & 781 & 925 & 22,6 & 17.8 & 74 & $280 / 5$ & LGT \\
\hline 8 & 922 & 910 & & & & $240 / 6$ & \\
\hline 9 & 981 & 904 & 21,7 & 14,4 & 63 & & \\
\hline 10 & 1513 & 850 & 18,4 & 12,4 & 68 & & \\
\hline 11 & 1514 & 850 & & & & $230 / 11$ & \\
\hline 12 & 1532 & 848 & & & & $230 / 11$ & \\
\hline 13 & 1852 & 817 & 16,6 & 8.6 & 59 & & \\
\hline 14 & 2142 & 790 & & & & $245 / 10$ & \\
\hline 15 & 2213 & 783 & 13,6 & 10,1 & 79 & & \\
\hline 16 & 2751 & 734 & & & & $220 / 9$ & \\
\hline 17 & 2768 & 733 & 11,4 & 4.4 & 62 & & \\
\hline 18 & 3152 & 700 & 8.6 & 4,2 & 74 & & LGT \\
\hline 19 & 3153 & 700 & & & & $240 / 11$ & \\
\hline 20 & 3380 & 681 & 7.4 & 3.6 & 77 & & \\
\hline 21 & 3851 & 643 & 5,2 & $-0,8$ & 65 & & \\
\hline 22 & 4701 & 579 & 0,0 & .35 & 77 & & \\
\hline
\end{tabular}

Gambar 5. Tabel Analisa Data Upper Air Sounding (http://www.weather.uwyo.edu/upperair/sounding.html.)

\section{Analisis Citra Satelit Himawari - 8}

Berdasarkan citra satelit yang menggunakan kanal IR10.8 $\mu \mathrm{m}$ (Infrared) yang terlihat pada Gambar 6 , suhu puncak awan pada lokasi kejadian hujan es menurun hingga dibawah -60 C sekitar pukul 08.00 UTC atau 15.00 LT di hampir keseluruhan lokasi kejadian hujan es. Bahkan, suhu puncak awan mencapai $-70^{\circ} \mathrm{C}$ pada pukul 08.30 UTC (15.30 LT). Hal ini mengindikasikan bahwa adanya awan $\mathrm{Cb}$ yang sangat dingin saat kejadian hujan es yang melanda Kota Depok.

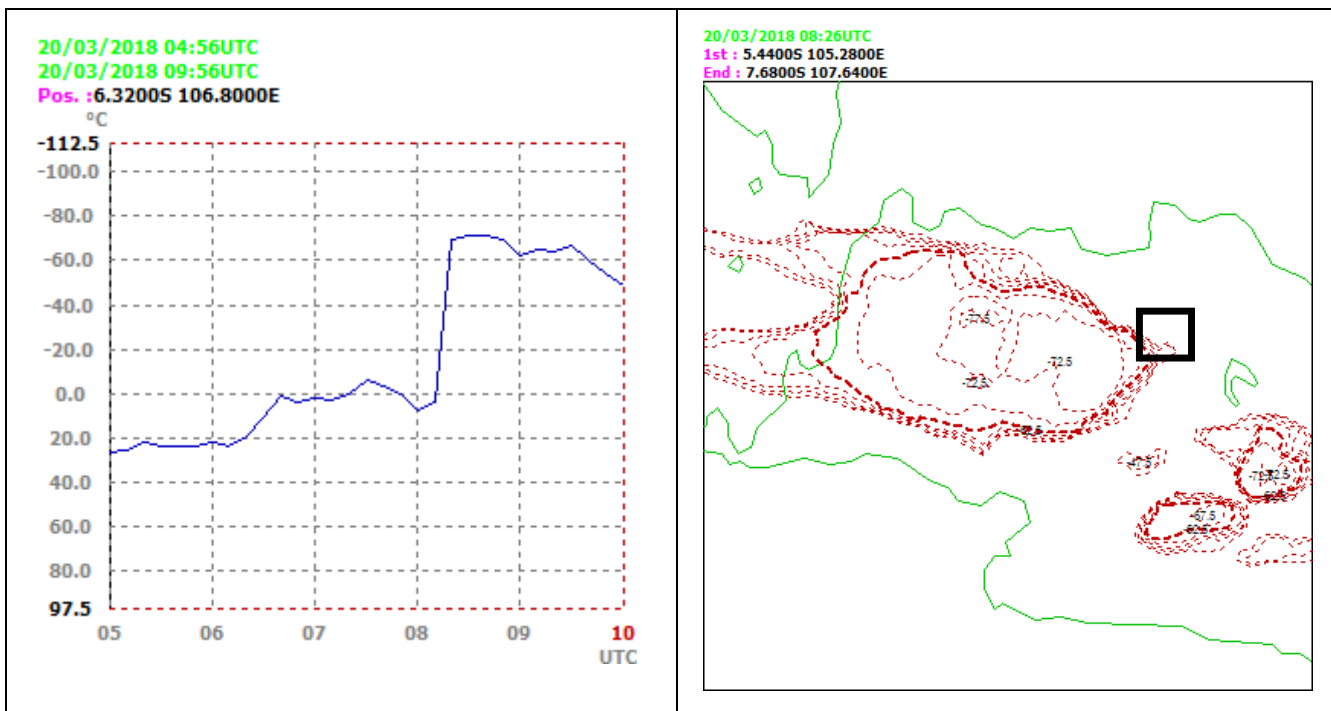

Gambar 6. a) Diagram Time Series Suhu Puncak Awan b) Contur Suhu Puncak Awan Pada Lokasi Hujan Es

Selain melakukan analisis untuk mengetahui suhu puncak awan menggunakan kanal IR10.8 $\mu \mathrm{m}$ (Infrared), analisis dinamika atmosfer dilakukan dengan menggunakan satelit Himawari-8 menggunakan produk RGB Day Microphysics untuk analisis pola spasial awan dengan intepretasi warna. Pemilihan produk RGB Day Microphysics dalam analisis awan konvektif lebih disebabkan karena aktivitas mikrofisika awan menjadi gambaran dinamika atmosfer saat kejadian hujan es di 
Kota Depok. Mikrofisika awan sendiri adalah proses dimana terjadi pelepasan energi (panas laten) dari uap air menjadi inti kondensasi dan butiran (tetes) air, adanya penyerapan molekul air pada inti kondensasi dan penggabungan antara butiran di dalam awan. Proses mikrofisika awan yang signifikan menunjukan adanya pertumbuhan awan $\mathrm{Cb}$ kuat.

Pada intepretasi produk RGB Day Microphysics yang dihasilkan dari pengolahan data satelit Himawari-8 menggunakan perangkat lunak SATAID, warna jingga menunjukan bahwa awan tersebut merupakan awan $\mathrm{Cb}$ yang sangat dingin, tebal (tinggi), dengan updraft yang kuat dan partikel es di dalamnya. Warna coklat kehijauan menunjukan awan Cirrus tipis yang dingin. Sedangkan untuk warna merah menunjukan awan-awan hujan yang dapat tumbuh menjadi awan yang lebih besar. Pada produk ini juga kita dapat melihat tekstur dari awan tersebut, dikarenakan dalam pengaturannya menggunakan kanal visible. Overshooting top dapat terlihat dari tekstur awan pada warna jingga, terdapat tekstur gelembung dengan warna sedikit gelap menandakan adanya updraft yang sangat kuat sehingga awan menembus lapisan Tropopause (lapisan batas antara Troposfer dengan Stratosfer).

Berdasarkan analisis produk RGB Day Microphysics seperti yang ditunjukan pada Gambar 7, kotak hitam menunjukan lokasi Kota Depok dimana kejadian hujan es berlangsung. Terlihat pada gambar, pada pukul 07.00 UTC atau 14.00 LT mulai tampak adanya warna merah di bagian selatan dan tenggara pada kotak hitam yang mengindikasikan adanya awan konvektif yang mulai tumbuh. Pada pukul 08.00 UTC (15.00 LT), terlihat pada kotak hitam keberadaan awan yang berwarna jingga yang menandakan awan sudah menjadi awan $\mathrm{Cb}$ yang memiliki updraft yang kuat dan telah terbentuknya partikel-partikel es di dalamnya. Warna jingga pada kotak hitam semakin meluas hingga pukul 08.30 UTC (15.30 LT) hingga 10.00 UTC (17.00 LT), dimana mulai tampak tekstur puncak awan yang bergelembung dan berwarna gelap yang menandakan adanya overshooting top.

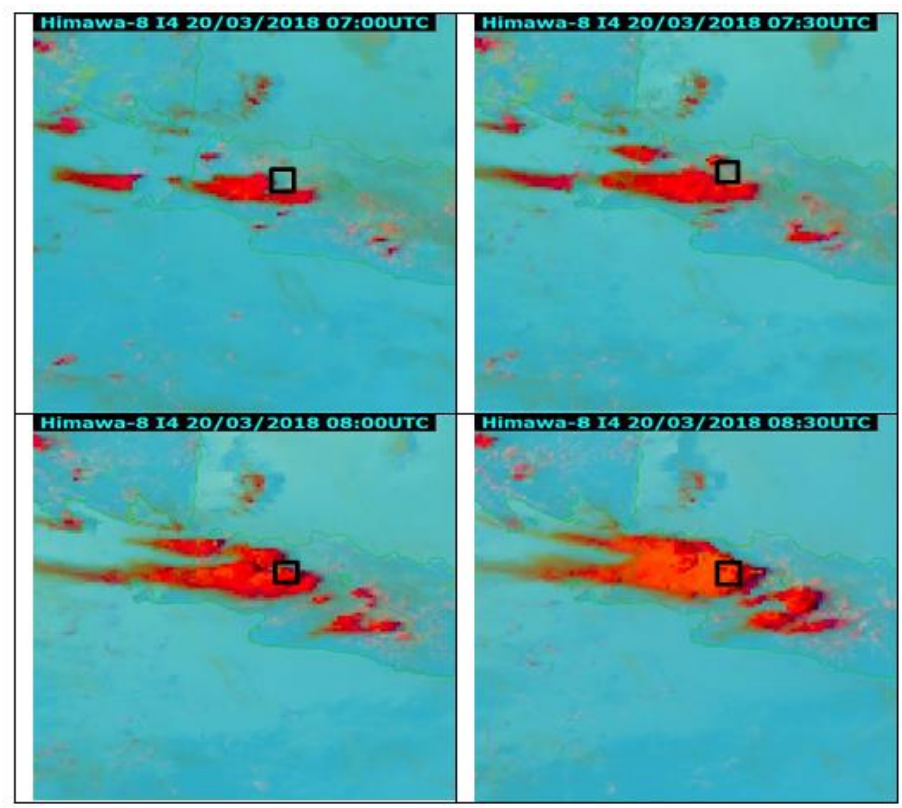




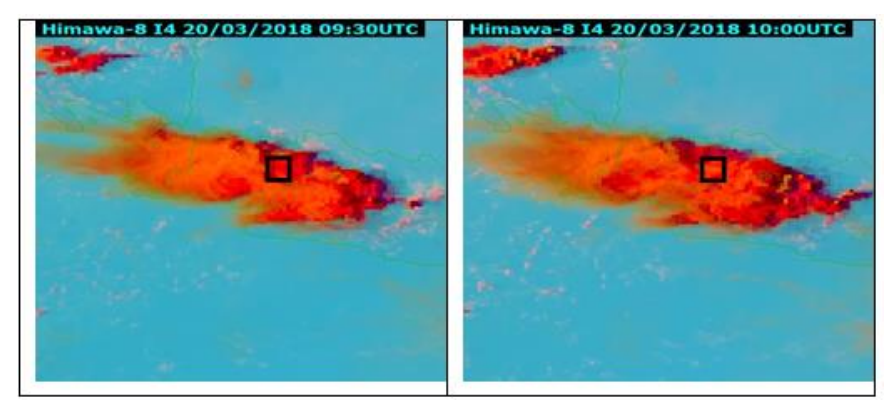

Gambar 7. Produk RGB Day Microphysics dari satelit Himawari-8 pada saat kejadian hujan es di Kota Bandung menggunakan pengaturan Red (VIS 0.8 $\mu \mathrm{m}$ ), Green (NIR $3.9 \mu \mathrm{m})$, Blue (IR $10.8 \mu \mathrm{m}$ reverse) dengan pengaturan gamma Red (1), Green (2.5), Blue (1) pada pukul 07.00 UTC, 07.30 UTC, 08.00 UTC, 08.30 UTC, 09.30 UTC, 10.00 UTC

\section{Kesimpulan}

Faktor global hingga lokal kurang berpengaruh terhadap kejadian hujan es di Depok. Sementara itu, analisis streamline pada tanggal 20 Maret menunjukkan adanya garis shearline di atas wilayah Depok. Selain itu, analisis streamline juga menunjukkan adanya sirkulasi eddy di perairan selat Makassar dekat dengan kawasan pulau Jawa pada pukul 08.00Z, sehingga meningkatkan potensi cuaca ekstrim di sekitar wilayah Pulau Jawa bagian barat.

Suhu permukaan turun secara signifikan dari $32^{\circ} \mathrm{C}$ pada waktu $07.00 \mathrm{Z}$ menjadi $28,4^{\circ} \mathrm{C}$ pada waktu 08.00 Z di Stasiun Klimatologi Bogor sebelum kejadian hujan es $(08.20 \mathrm{Z})$ tanggal 20 Maret 2017. Penurunan suhu secara signifikan sebesar $3,6^{\circ} \mathrm{C}$ juga disertai dengan kenaikan kelembaban secara signifikan dari $60 \%$ menjadi $71 \%$ di Stasiun Klimatologi Bogor, sedangkan untuk Stasiun Meteorologi Kemayoran juga mengalami peningkatan kelembaban dari $67 \%$ menjadi $72 \%$.

Analisis time series suhu puncak awan tanggal 20 Maret 2018 menunjukkan adanya penurunan suhu puncak awan yang sangat signifikan hingga mencapai suhu sekitar $-70^{\circ} \mathrm{C}$ dari yang mulanya bersuhu sekitar $20^{\circ} \mathrm{C}$.

Analisis menggunakan data upper air sounding menggunakan software Raob 5.7R di Stasiun Meteorologi Cengkareng pada tanggal 20 Maret 2018 jam 00 UTC diperoleh informasi ketinggian lapisan freezing level dengan suhu udara sebesar 0 ${ }^{\circ} \mathrm{C}$ berada pada ketinggian 4701 meter di atas permukaan laut.

\section{Ucapan terima kasih}

Penulis mengucapkan terima kasih kepada semua dosen STMKG yang memberikan arahan serta bimbingan kepada taruna-taruni didikannya untuk menjadi kader ahli di bidang meteorologi serta rekan-rekan yang tetap menjaga solidaritas untuk tetap saling membantu dan bekerja sama.

\section{DaftarPustaka}

1. M. Karmini, Hujan Es (hail) di Jakarta, 20 April 2000. Jurnal Sains dan Teknologi Modifikasi Cuaca, Vol. 1 No.1 (2000) p. 27-32

2. A. Fadholi, Analisa Kondisi Atmosfer pada Kejadian Cuaca Ekstrem Hujan Es (hail). Simetri: Jurnal Ilmu Fisika Indonesia Vol. 1 No. 2D (2012). 
3. D. Rosenfeld, W. L. Woodley, A. Lerner, G. Kelman, D. T. Lindsey, Satellite detection of severe convectivestorms by their retrieved vertical profiles of cloud particle effective radius and thermodynamic phase, J. Geophys. Res., 113 (2008) D04208.

4. A. Merino, L. López, J. L. Sánchez, E. G. Ortega, E. Cattani, V. Levizzani, Daytime identification of summer hailstorm cells from MSG data, Nat. Hazards Earth Syst. Sci., Vol. 14 (2014) p. 1017-1033.

5. L. Guihua, Y. Xing, J. Ling, D. Jin. (2009). Satellite Retrieval of a Strong Hailstorm Process, Atmospheric and Oceanic Science Letters, Vol. 2 Issue 2 (2009) p. 103-107. 